\title{
EFEKTIFITAS THE HEART TECHNIQUE TERHADAP PENURUNAN KECEMASAN PADA IBU HAMIL
}

\author{
Lila Kusuma Rahayu ${ }^{1}$, Widayati ${ }^{2}$, Wahyu Kristiningrum ${ }^{3}$ \\ 1Program S1 Gizi Fakultas Ilmu Kesehatan Universitas Ngudi Waluyo. \\ email: lila.adhicandra@gmail.com \\ 2Program S1 Kebidanan Fakultas IImu Kesehatan Universitas Ngudi Waluyo. \\ email: widayati.alif@gmail.com \\ 3Program S1 Kebidanan Fakultas IImu Kesehatan Universitas Ngudi Waluyo. \\ email: kristiningrumwahyu@gmail.com
}

\begin{abstract}
Background: The Heart Technique (THT) is a self-therapy technique that is performed on oneself and has been clinically tested to effectively deal with problems that are related to behavior and emotions. Every mother experiences symptoms of pregnancy - different, most pregnant women experience anxiety in dealing with their pregnancy. Pregnant women who experience high levels of anxiety can increase risk of preterm birth, besides pregnant women with high anxiety when pregnant will increase the risk of hypertension in pregnancy. The risk of hypertension can be in the form of stroke, seizures, and even death in the mother and fetus. If this is allowed to happen, the mortality and morbidity rates in pregnant women will increase.

Purpose: to determine the effectiveness of The Heart Technique in reducing anxiety in pregnant women.

Methods: This research was a quasi-experimental study. The treatment of THT was given to 17 pregnant women. Pregnancy anxiety is measured before and after pregnant women do THT. The data obtained were processed using a dependent $t$-test because the data were normally distributed.

Results: Research that has been done shows that THT can reduce anxiety in pregnant women. This can be seen from the results of data processing obtained is the calculated value of -7.115 with a $p$ value of 0,000 so the value is $0,000<\alpha(0.05)$.

Conclusion: The Heart Technique is effective against Decreasing Anxiety in Pregnant Women in Langensari Village, Ungaran Barat, Semarang Regency.

Suggestion: In providing pregnancy services, it is expected that health workers can provide additional information about The Heart Technique to pregnant women
\end{abstract}

Keywords: The heart technique, pregnant women, anxiety

\section{ABSTRAK}

Latar belakang : The Heart Technique (THT) adalah teknik swaterapi yang dilakukan pada diri sendiri dan telah teruji klinis secara efektif untuk mengatasi masalah yang berhubungan dengan perilaku dan emosi. Adanya ibu hamil yang mengalami kecemasan dalam masa kehamilan, dimana yang nantinya dapat berpengaruh terhadap kondisi bayi yang dikandungnya. Ibu hamil yang mengalami kecemasan, maka bayi yang dikandungan juga akan mengalami kecemasan. Hal ini dikarenakan, apapun yang dirasakan oleh ibu, maka bayi yang ada didalam kandungan juga akan merasakannya.

Tujuan : untuk mengetahui keefektifan The Heart Technique dalam menurunkan kecemasan pada ibu hamil.

Metode : Penelitian yang dilakukan ini termasuk penelitian quasi eksperimen. Perlakuan THT diberikan pada ibu hamil yang berjumlah 17 orang. Kecemasan ibu hamil diukur sebelum dan sesudah ibu hamil melakukan THT. Data yang diperoleh diolah menggunakan uji dependent t-test karena datanya berdistribusi normal. 
Hasil : Penelitian yang sudah dilakukan menunjukkan bahwa THT dapat menurunkan angka kecemasan pada ibu hamil. Hal ini terlihat dari hasil pengolahan data yang didapatkan yaitu nilai $t$ hitung sebesar $-7,115$ dengan nilai $p$ sebesar 0,000 , sehingga nilai $0,000<\alpha(0,05)$.

Kesimpulan: The Heart Technique efektif terhadap Penurunan Kecemasan pada Ibu Hamil di Kelurahan Langensari Ungaran Barat Kabupaten Semarang.

Saran : Dalam memberikan pelayanan kehamilan, diharapkan tenaga kesehatan dapat memberikan informasi tambahan tentang The Heart Technique pada bu hamil.

Kata kunci : The heart technique, ibu hamil, kecemasan

\section{PENDAHULUAN}

Angka kematian dari waktu ke waktu menggambarkan status kesehatan masyarakat secara kasar, kondisi atau tingkat permasalahan kesehatan, kondisi lingkungan fisik dan biologik secara tidak langsung. Angka tersebut dapat digunakan sebagai indikator dalam penilaian keberhasilan pelayanan kesehatan dan program pembangunan kesehatan. Salah satu kebijakan pembangunan kesehatan masyarakat melalui usaha pencegahan dan pengurangan morbiditas, mortalitas dan kecacatan terutama pada bayi, anak balita, wanita hamil, pencegahan, pengobatan penyakit dan rehabilitasi. Program ini bertujuan untuk meningkatkan derajat kesehatan ibu, anak, remaja usia subur, dan usia lanjut agar tercipta kesehatan reproduksi yang optimal (Dinkes Jateng, 2012).

Angka Kematian lbu di Provinsi Jawa Tengah pada tahun 2015 menunjukkan 111,16 per $100.000 \mathrm{KH}$ (619 kasus). AKI menunjukkan penurunan pada tahun 2016 sejumlah 365 kasus (Dinas Kesehatan Provinsi Jawa Tengah, 2016). Angka Kematian Ibu wilayah di Kabupaten Semarang sejumlah 103,39 per $100.000 \mathrm{KH}$ (15 kasus) tahun 2016 mengalami penurunan bila dibandingkan tahun 2015, AKI sebesar 120,34 per $100.000 \mathrm{KH}$ (17 kasus) (Dinas Kesehatan Kabupaten Semarang, 2016).

Angka kematian ibu di Kabupaten Semarang tahun 2017 meningkat bila dibandingkan dengan tahun 2016. Bila di tahun 2016 AKI sebesar 103,39 per $100.000 \mathrm{KH}$ (14 kasus). Maka di tahun 2017 menjadi 111,83 per $100.000 \mathrm{KH}(15$ kasus). Data ini menunjukkan bahwa AKI di Kabupaten Semarang mengalami peningkatan dibandingkan sebelumnya dan belum dapat mencapai target sebesar 102 per $100.000 \mathrm{KH}$. Jumlah kasus kematian ibu di wilayah kabupaten semarang pada tahun 2017 yaitu terdapat 15 kasus. Puskesmas Wilayah kerja Bergas menyumbangkan AKI pada tahun 2017 yaitu sejumlah 1 kasus yang disebabkan Preeklamsi (profil Kesehatan Kabupaten Semarang Tahun 2017)
Menurut Astria (2009) mengatakan bahwa ibu hamil yang mengalami kecemasan tingkat tinggi dapat meningkatkan resiko kelahiran bayi prematur. Penyebab kematian ibu di Propinsi Jawa Tengah masih sama yaitu karena perdarahan, eklamsi, dan infeksi. Terjadinya perdarahan yang mengakibatkan kematian ibu sewaktu hamil, bersalin atau nifas. Penelitian lain menunjukkan bahwa ibu hamil dengan kecemasan yang tinggi ketika hamil akan meningkatkan risiko hipertensi pada kehamilan. Risiko hipertensi dapat berupa terjadinya stroke, kejang, bahkan kematian pada ibu dan janin (Astria, 2009).

Faktor-faktor maternal yaitu kecemasan, kurang persiapan dan rasa takut dapat berinteraksi dengan faktor-faktor yang lain yang menyebabkan partus lama. Saat cemas ibu ibu juga akan merasakan perasaan takut akan kelancaran persalinannya (Padilla, 2014). Kondisi psikologi seperti kecemasan atau takut sangat berpengaruh pada fungsi tubuh secara fisik. Pada saat cemas dan takut pembuluh darah mengalami vasokontraksi atau menyempit sehingga aliran darah keseluruh tubuh akan terhambat atau berkurang. Hal ini sangat berpengaruh pada fungsi organ misalnya organ-organ yang terlibat dalam persalinan menjadi tidak berfungsi secara baik. Seorang ibu yang mengalami stres berlebihan akan berakibat ke anak berisiko dilahirkan dengan berat badan lahir rendah (BBLR), perkembangan sarafnya tidak seimbang, dan lahir prematur (Padilla 2014).

Menurut Hanifa (1999) dalam Rizki cahya (2011), mengatakan bahwa akibat kecemasan yang dapat timbul selama kehamilan yaitu antara lain, partus prematurus ini disebabkan oleh ketegangan psikis tekanan kehidupan modern dan diikutsertakan wanita dalam industri, nyeri persalinan yang merupakan faktor utama yang menyebabkan rasa sakit atau nyeri dalam persalinan. Partus lama disebabkan karena faktorfaktor yang mengakibatkan his kurang baik dan pembukaan kurang lancar 
Menurut MNH (Maternal Neonatal Health) Asuhan antenatal atau yang dikenal antenatal care merupakan prosedur rutin yang dilakukan oleh petugas (dokter/bidan/perawat) dalam membina suatu hubungan dalam proses pelayanan pada ibu hamil untuk persiapan persalinannya. Dengan memberikan asuhan antenatal yang baik akan menjadi salah satu tiang penyangga dalam safe motherhood dalam usaha menurunkan angka kematian dan kesakitan ibu dan perinatal. Pemeriksaan ANC meliputi anamnesis dan pemeriksaan fisik dengan seksama untuk menilai apakah perkembangan kehamilan berlangsung normal. Kualitas pelayanan antenatal diberikan selama masa hamil secara berkala sesuai dengan pedoman pelayanan antenatal yang telah ditentukan untuk memelihara serta meningkatkan kesehatan ibu selama hamil sesuai dengan kebutuhan sehinggga dapat menyelesaikan kehamilan dengan baik dan melahirkan bayi sehat, (Romauli, 2011).

Studi pendahuluan yang penulis lakukan di Kelurahan Langensari Ungaran Timur, Kabupaten Semarang bahwa terdapat ibu hamil yang mengalami kegelisahan dalam menjalani kehamilan. Pemeriksaan yang dilakukan oleh bidan sudah sesuai dengan standar, akan tetapi bidan belum pernah memberikan asuhan dalam

\section{HASIL}

\section{Analisa Univariat}

Deskripsi kecemasan ibu hamil sebelum melakukan The Heart Techniqu.

Tabel 1.

Deskripsi kecemasan ibu hamil sebelum melakukan The Heart Techniqu

\begin{tabular}{ccccccc}
\hline Variabel & Perlakuan & $\mathrm{N}$ & Mean & SD & Min & Max \\
\hline \multirow{2}{*}{ Kecemasan } & Sebelum & 17 & 42,71 & 4,043 & 37 & 48 \\
& Sesudah & 17 & 38,18 & 3,147 & 34 & 43 \\
\hline
\end{tabular}

Berdasarkan tabel 1 dapat diketahui bahwa dari 17 ibu hamil yang diteliti, sebelum ibu hamil melakukan The Heart Techniqu standar devisinya 4,043 dan kecemasan yang paling rendah sebesar 37 sedangkan yang paling tinggi sebesar 48. Sesudah ibu hamil melakukan The Heart Techniqu standar devisinya 3,147 dan kecemasan yang paling rendah sebesar 34 sedangkan yang paling tinggi sebesar 43. mengalatasi kecemasan yang dialami oleh ibu hamil dengan menggunakan The Heart Technique.

\section{METODE PENELITIAN}

Penelitian dilakukan di Kelurahan Langensari Ungaran Barat Kabupaten Semarang. Penelitian yang dilakukan ini termasuk penelitian quasi eksperimen, yang respondennya diukur kecemasan sebelum dan sesudah dilakukan THT. Adapun populasi dalam penelitian ini yaitu ibu hamil di Kelurahan Langensari, sedangkan yang menjadi responden yaitu ibu hamil yang mengalami kecemasan yang berjumlah 17 ibu hamil. Observasi yang dilakukan sebelum disebut pre-test dan observasi sesudah eksperimen disebut post test, yang diukur adalah kecemasan pada ibu hamil. Ibu hamil ini diukur tingkat kecemasannya sebelum dan sesudah dilakukan The Heart Technique. Uji normalitas datanya menggunakan Uji Kolmogorov karena datanya $<50$ responden yaitu sejumlah 17 responden. Hasil uji normalitas datanya bahwa data penelitian dinyatakan berdistribusi normal dikarenakan box berada ditengah, garis horizontal berada ditengah box dan tidak berada di plot-plot diatas atau dibawah box atau nilai $p>0,05$. Oleh karena itu, uji bivariatnya menggunakan $\mathrm{Uji}$ Dependent T-test.

\begin{tabular}{clrrl} 
Analisa Bivariat & \multicolumn{1}{c}{$\begin{array}{c}\text { Tabel } 2 . \\
\text { Uji Normalitas }\end{array}$} \\
\hline \multirow{2}{*}{ Variabel } & Perlakuan & $\mathrm{N}$ & $\begin{array}{c}\text { P- } \\
\text { value }\end{array}$ & Kesimpulan \\
\hline \multirow{2}{*}{ Kecemasan } & Pre & 17 & 0,058 & Normal \\
& Post & 17 & 0,200 & Normal \\
\hline
\end{tabular}


Tabel 3.

Keefektifan The Heart Techniqu terhadap kecemasan ibu hamil di Kelurahan Langensari

\begin{tabular}{clccccc}
\hline Variabel & Perlakuan & $\mathrm{N}$ & Mean & SD & $\mathrm{T}$ & Nilai $p$ \\
\hline \multirow{2}{*}{ Kecemasan } & $\begin{array}{l}\text { Sebelum } \\
\text { Sesudah }\end{array}$ & 17 & 4,529 & 2,625 & 7,115 & 0,000 \\
\hline
\end{tabular}

Berdasarkan uji $t$ test (Paired), didapatkan nilai $t$ hitung sebesar $-7,115$ dengan nilai $p$ sebesar 0,000 . Terlihat bahwa nilai $0,000<a(0,05)$, ini menunjukkan bahwa ada perbedaan yang signifikan terhadap kecemasan setelah dilakukan The Heart Techniqu di Kelurahan Langensari Ungaran Barat Kabupaten Semarang.

\section{PEMBAHASAN}

Gambaran kecemasan sebelum dan sesudah dilakukan The Heart Techniqu

Berdasarkan penelitian yang telah dilakukan di Kelurahan Langensari hasil rata-rata kecemasan ibu hamil sebelum diberikan perlakuan yaitu 42,71 , sedangkan rata-rata kecemasan ibu hamil sesudah dilakukan The Heart Techniqu yaitu 38,18. Berdasarkan hasil tersebut dapat disimpulkan bahwa terjadi penurunan rata-rata kcemasan yang dialami oleh ibu hamil sesudah ibu hamil melakukan The Heart Techniqu. Hal ini sesuai dengan yang dinyatakan oleh Adi W Gunawan bahwa The Heart Techniqu merupakan teknik swaterapi atau terapi yang dilakukan pada diri sendiri guna untuk mengatasi permasalahan yang berhubungan dengan perilaku dan emosi (Gunawan, 2018).

The Heart Technique pada orang dewasa dapat membantu mengatasi masalah antara lain luka batin, perasaan diri tidak berharga, tidak percaya diri, takut bicara di depan umum, mudah emosi, cemas atau ketakutan berlebih, perasaan diri ditolak, mudah panik, takut menikah, kesedihan mendalam, kesulitan diet, beragam fobia, kesepian, kebiasaan menunda, adiksi game atau video, sakit psikosomatis, dan masih banyak lagi.(Gunawan, 2018)

Kondisi psikologi seperti kecemasan atau takut sangat berpengaruh pada fungsi tubuh secara fisik. Pada saat cemas dan takut pembuluh darah mengalami vasokontraksi atau menyempit sehingga aliran darah keseluruh tubuh akan terhambat atau berkurang. Hal ini sangat berpengaruh pada fungsi organ misalnya organ-organ yang terlibat dalam persalinan menjadi tidak berfungsi secara baik. Seorang ibu yang mengalami stres berlebihan akan berakibat ke anak berisiko dilahirkan dengan berat badan lahir rendah (BBLR), perkembangan sarafnya tidak seimbang, dan lahir prematur (Padilla 2014).
Keefektifan The Heart Techniqu terhadap penurunan kecemasan pada ibu hamil di Kelurahan Langensari Kabupaten Semarang

Berdasarkan hasil penelitian yang telah dilakukan di Kelurahan Langensari, bahwa dari 17 responden, mengalami penurunan kecemasan. Berdasarkan uji $t$-test (Paired) didapatkan nilai $t$ hitung sebesar 7,115 dengan nilai $p$ sebesar 0,000 ., sehingga nilai $p 0,000<\alpha(0,05)$. Hal ini dikatakan terdapat perbedaan yang signifikan pada The Heart Technique terhadap Penurunan Kecemasan pada Ibu Hamil di Kelurahan Langensari Ungaran Barat Kabupaten Semarang. Sehingga dapat disimpulkan bahwa The Heart Technique dapat menurunkan kecemasan yang dialami oleh ibu hamil. Didalam mempraktikkan The Heart Techniqu yang dibutuhkan adalah niat dan keinginan untuk menghilangkan emosi tersebut. Responden/lbu hamil diajari untuk mengenali apa yang menjadi penyebab kecemasannya kemudian menentukan intensitas emosi dengan menggunakan skala 0-10. Selanjutnya mereset jalur energi lalu tracing untuk meniatkan melepaskan sisa emosi/ penyebab kecemasannya kemudian priming the subconscious for change dengan menjawab 7 pertanyan kunci setelah itu cek final dengan cek perasaan emosi turun ke skala berapa, bila skala sudah diangka 0 maka The Heart Techniqu dapat dihentikan namun bila masih ada sisa dilanjutkan ke tahap reset jalur energi tracing kemudian pelepasan emosi. Satu rangkaian dalam mempraktikan The Heart Technique sudah dapat langsung mengukur seberapa sisa emosi/kecemasan dari masingmasing responden/ ibu hamil. Dengan yang demikian The Heart Technique efektif dapat menurunkan kecemasan yang dialami oleh ibu hamil (Gunawan, 2018).

Protokol THT dirancang sedemikian rupa sehingga sangat mudah dipraktikkan oleh siapa saja tanpa harus mengerti hipnosis, hipnoterapi, cara kerja pikiran, atau trance. Sebelum diajarkan ke publik, THT telah diujicobakan selama satu setengah tahun kepada lebih dari 100 subjek/klien, terbukti efektif memberi hasil terapi positif dan konsisten, dengan tingkat keberhasilan di atas $95 \%$. (Gunawan, 2018) 


\section{KESIMPULAN}

Sesuai dengan hasil penelitian yang dilakukan oleh peneliti, maka kesimpulannya yaitu The Heart Technique efektif terhadap Penurunan Kecemasan pada lbu Hamil di Kelurahan Langensari Ungaran Barat Kabupaten Semarang

\section{SARAN}

Dalam memberikan pelayanan kehamilan, diharapkan tenaga kesehatan dapat memberikan informasi tambahan tentang The Heart Technique ibu hamil.

\section{DAFTAR PUSTAKA}

Astria, Y. (2009). Hubungan karakteristik Ibu Hamil Trimester III dengan kecemasan menghadapi persalinan di Poliklinik Kebidanan dan Kandungan Rumah Sakit $X$ Jakarta. Diunduh dari http://perpus. fkik. uinjkt. ac. id.

Cahya, Rezky. (2011). Faktor - faktor yang mempengaruhi tingkat kecemasan ibu hamil. Karya tuliis ilmiah. Semarang

Dinas Kesehatan provinsi Jawa Tengah. (2012). Laporan Tahunan Seksi Kesehatan Ibu Dan Anak Bidang Bina Kesehatan Masyarakat 2012. Dinkes provinsi jawa tengah

Dinas Kesehatan Provinsi Jawa Tengah, (2016). Dinas Kesehatan Provinsi Jawa Tengah. Profil Kesehatan Provinsi Jawa Tengah Tahun 2016.
DinKes Kab Semarang. (2016). Profil Kesehatan Kabupaten Semarang tahun 2016. Semarang: Dinas Kesehatan Kabupaten Semarang

DinKes Kab Semarang. (2017). Profil Kesehatan Kabupaten Semarang tahun 2017. Semarang: Dinas Kesehatan Kabupaten Semarang

Endro. (2018, Juni). Adi W. Gunawan Rilis THT untuk Atasi Masalah Perilaku dan Emosi. Diunduh dari https://berau.prokal.co/read/news/55964-adiw-gunawan-rilis-tht-untuk-atasi-masalahperilaku-dan-emosi.html tanggal 23 Juni 2020.

Gunawan, Adi W.(2018) Sejarah The Heart Technique. Diunduh dari :

https://www.theheart.or.id/page/view/5_sejarah_the _heart_technique.tanggal 23 Juni 2020

Gunawan, Adi W.(2018) Teknologi di Balik The Heart Technique.

Gunawan,Adi W. (2018) The Heart Technique. Surabaya: Transformasi Insan Mulia. Diunduh dari :

https://www.adiwgunawan.com/articles/teknologi-dibalik-the-heart-technique tanggal 23 Juni 2020

Padilla. (2014). Keperawatan maternitas. Yogyakarta: Nuha Medika

Romauli, suryati. (2011). Asuhan Kebidanan 1 Konsep Dasar Asuhan Kehamilan. Yogyakarta : Nuha Medika 